\title{
INVESTIGATION ON HIGH THERMAL STABILITY AND CREEP RESISTANT MODIFIED INCONEL 718 WITH COMBINED PRECIPITATION OF $\gamma^{\prime \prime}$ AND $\gamma^{\prime}$ *
}

Xishan Xie, Qiang Liang, Jianxin Dong, Weigang Meng and Zhichao Xu University of Science and Technology Beijing, Beijing 100083, China

\author{
Mengzhe Chen \\ Beijing Laboratory of Electron Microscopy \\ Chinese Academy of Sciences \\ Beijing 100080 , China \\ Fugang Wang, Yu Cai and Junshan Zhang \\ Dalian University of Technology, Dalian 116024, China \\ Ning Wang, E. Andrieu and A. Pineau \\ Centre des Materiaux, Ecole des Mines, B. P. 87, 91003 Evry Cedex \\ URA CNRS DO866, France
}

\begin{abstract}
$\underline{\text { Abstract }}$
One of the recent advances in INCONEL 718 development is intended to find a modified Alloy 718 with high thermal structure stabil ity and creep resistance to be used beyond the ceiling temperature of $650^{\circ} \mathrm{C}$. Twel ve heats of modified Alloy 718 with chemical composition variation were designed to study the effect of $\mathbf{A l}, \mathbf{T i}, \mathbf{N b}$ and Mo on $\gamma^{\prime \prime}$ and $\gamma^{\prime}$ precipitation morphology and on microstructure stability and high temperature mechanical properties above $650^{\circ} \mathrm{C}$. Detail TEM and high resol ution electron microscopy (HREM) study has shown that associated precipitation and compact morphology of $\gamma^{\prime \prime}$ and $\gamma^{\prime}$ in modified 718 Alloys characterize with higher thermal stability than separate precipitation of $\gamma^{\prime \prime}$ and $\gamma^{\prime}$ in conventional INCONEL 718. Creep rupture life depends not only on $\mathrm{Nb}+\mathrm{Al}+\mathrm{Ti}$ content but also on cocfficient $\mathbf{k}=$ $\sqrt{(\mathrm{Al}+\mathrm{Ti} / \mathrm{Nb})^{2}+(\mathrm{Al} / \mathrm{Ti})^{2}} \cdot \mathrm{Nb}$. Long time aging stability study at 650,700 and $750^{\circ} \mathrm{C}$ for $5000 \mathrm{hrs}$ has shown that the modified Alloy 718 with associated precipitation and compact morphology of $\gamma^{\prime \prime}$ and $\gamma^{\prime}$ expresses excellent thermal structural stability.
\end{abstract}

\footnotetext{
* This research project in supported by China National Natural Science Foundation under the contract NO: 58971044 


\section{Introduction}

$\gamma^{\prime \prime}$ (bct $\mathrm{DO}_{22}$ structure) and $\gamma^{\prime}$ (fcc $\mathrm{Ll}_{2}$ structure) are typical strengthening phases in nickel-base superalloy. The unique strengthening effect of $\gamma^{\prime \prime}-\mathrm{Ni}_{9} \mathbf{N b}$ and $\gamma^{\prime}-\mathbf{N i}_{3}$ (TiAlNb) helps Alloy 718 to have wide industrial application. Because of the stability limitation of $\gamma^{\prime \prime}$ the highest service temperature of Alloy 718 can reach $650^{\circ} \mathrm{Conly}$. However, the stability of $\gamma^{\prime}$ strengthening phase in nickel-base superalloys is much higher than $650^{\circ} \mathrm{C}$. Basic idea of this research is intended to find a combination of high strengthening effect of $\gamma^{\prime \prime}$ and good stability of $\gamma^{\prime}$ in modified INCONEL 718 to be allowed alloy to use at temperature higher than $650^{\circ} \mathrm{C}$.

Since 1973 R. Cozar and A. Pineau (1) publ ished a pioneer paper on modified Alloy 718 with compact morphol ogy of $\gamma^{\prime \prime}$ and $\gamma^{\prime}$ to be possible on higher thermal stability as shown in age hardening test results. After 15 years a series of papers (2-9) modifying the chemical composition with variation of $\mathrm{Al}$, Ti and $\mathrm{Nb}$ contents in Alloy 718 has shown that mechanical properties beyond $650^{\circ} \mathrm{C}$ can be improved with either the noncompact or the compact morphology of $\gamma^{\prime \prime}$ and $\gamma^{\prime}$ obtained by appropriate heat treatment. However, long time thermal stability study from the point of view of strengthening mechanisms and creep resistance has not appeared yet. This investigation concentrates on TEM analyses of $\gamma^{\prime \prime}$ and $\gamma^{\prime}$ precipitation morphology and their long time structure stability beyond $650^{\circ} \mathrm{C}$ and follows with creep tests in point of view from high temperature strengthening effect. The first phase goal of this research tries to get fundamental understanding on stability improvement that helps modified Alloy 718 development.

\section{Materials and Experimental Procedure}

Twelve heats of experimental alloys were melted in 25 and $50 \mathrm{~kg}$ VIM furnaces. All VIM ingots were homogenized by 2 step high temperature treatment (1st step for Laves phase solution and 2nd step for homogenization of $\mathbf{N b}$ ), Then ingots were forged down to $40 \times 40 \mathrm{~mm}$ billets and finally hot rolled for $18 \mathrm{~mm}$ diameter bars (except 2 heats of powder metallurgy prepared modified 718 alloys). Chemical composition of 12 modified 718 alloys are devided in 3 groups and listed in Table $I$.

Group A consists of 3 alloys with different levels of $\mathrm{Nb}(5.08,4.38$ and $3.44 \%)$. Alloy 11 and 13 compose of higher contents of Ti and Al for $\gamma^{\prime}$ strengthening precipitation. Alloy 15 was designed with high content of Mo (7\%) for strong sol id sol ution strengthening. Group B consists of 7 alloys with 3 levels of $\mathrm{Nb}(\sim 5.5,5.1$ and 4. $75 \%$ ) and higher contents of $\mathrm{Al}, \mathrm{Ti}$ and higher ratios of $\mathrm{Al}+\mathrm{Ti} / \mathrm{Nb}$ and $\mathrm{Al} / \mathrm{Ti}$ also. All 7 heats were micrn-allnyed with $\sim 50 \mathrm{ppm} \mathrm{Mg}$ for hot workability and ductility improvement. Alloy 10 was considered as conventional Alloy 718. Gr oup $C$ consists of 2 alloys and specially prepared by powder metallurgy in IMPHY, France. Alloy 975 was considered as Super 718 with high content of $\mathrm{Nb}(5.39 \%)$ and normal content of $\mathrm{Ti}$ $(\sim 1 \%)$ and Al $(\sim 0.5 \%)$. Alloy 976 (similar to Alloy 4 in Group B) was also specially designed for associated precipitation and compact morphology of $\gamma^{\prime \prime}$ and $\gamma^{\prime}$ and therefore high thermal stability with medium level of $\mathrm{Nb}(\sim 5 \%)$ and high contents of Al $(1.05 \%)$ and $\mathrm{Ti}(1.22 \%)$ and also high atomic sum of $\mathrm{Al}+\mathrm{Ti}+\mathrm{Nb}$ and atomic ratios of $\mathrm{Al}+\mathrm{Ti} / \mathrm{Nb}$ and $\mathrm{Al} / \mathrm{Ti}$ for keeping a good combination of $\gamma^{\prime \prime}$ and $\gamma^{\prime}$ precipitation. 
Table I Chemical Composition of Experimental Alloys

\begin{tabular}{|c|c|c|c|c|c|c|c|c|c|c|c|c|c|c|}
\hline \multirow[b]{2}{*}{ Group } & \multirow[b]{2}{*}{ Alloy } & \multicolumn{10}{|c|}{$w t \%$} & \multicolumn{3}{|c|}{ at $\%$} \\
\hline & & $\mathrm{C}$ & $\mathrm{Cr}$ & $\mathrm{Fe}$ & $\mathrm{Ni}$ & Mo & $\mathrm{Nb}$ & $\mathrm{Al}$ & $\mathrm{Ti}$ & B & $\mathrm{Mg}$ & $\begin{array}{c}\mathrm{Al}+\mathrm{Ti} \\
/ \mathrm{Nb}\end{array}$ & $\begin{array}{l}\text { Al } \\
/ \mathrm{Ti}\end{array}$ & $\begin{array}{l}\mathrm{Al}+\mathrm{Ti} \\
+\mathrm{Nb}\end{array}$ \\
\hline \multirow{3}{*}{ A } & 11 & 0.075 & 19.01 & 19.53 & bal. & 2.98 & 5.08 & 0.73 & 1.14 & 0.008 & -- & 0.93 & 1.14 & 6.09 \\
\hline & 13 & 0.063 & 19.05 & 20.23 & bal. & 3.02 & 4.38 & 0.72 & 1.13 & 0.007 & -- & 1.07 & 1.13 & 5.62 \\
\hline & 15 & 0.057 & 19.01 & 17.72 & bal. & 7.04 & 3.44 & 0.68 & 0.595 & 0.011 & -- & 1.01 & 2.01 & 4.37 \\
\hline \multirow{7}{*}{ B } & 1 & 0.02 & 19.06 & 18.70 & bal. & 3.04 & 5.47 & 0.98 & 1.02 & 0.0034 & 0.0065 & 0.98 & 1.71 & 6.75 \\
\hline & 2 & 0.03 & 18.94 & 18.56 & bal. & 3.08 & 5.51 & 1.15 & 1.14 & 0.0024 & 0.0075 & 1.12 & 1.79 & 7.24 \\
\hline & 4 & 0.02 & 19.12 & 18.76 & bal. & 3.04 & 5.09 & 0.98 & 1.17 & 0.0024 & 0.0056 & 1.11 & 1.49 & 6.65 \\
\hline & 6 & 0.02 & 19.04 & 18.30 & bal. & 2.75 & 5.06 & 1.25 & 1.39 & 0.0025 & 0.0057 & 1.38 & 1.60 & 7.45 \\
\hline & 7 & 0.02 & 18.74 & 19.25 & bal. & 3.04 & 4.72 & 0.86 & 1.19 & 0.0029 & 0.0056 & 1.12 & 1.28 & 6.19 \\
\hline & 9 & 0.02 & 19.04 & 19.31 & bal. & 3.04 & 4.75 & 1.28 & 1.37 & 0.0015 & 0.0055 & 1.49 & 1.66 & 7.28 \\
\hline & 10 & 0.02 & 18.88 & 18.36 & bal. & 3.00 & 5.14 & 0.46 & 1.03 & 0.0033 & 0.0039 & 0.70 & 0.79 & 5.44 \\
\hline \multirow{2}{*}{ C } & 975 & 0.04 & 18.00 & 18.80 & bal. & 2.97 & 5.39 & 0.54 & 1.02 & 0.0044 & trace & 0.71 & 0.94 & 5.76 \\
\hline & 976 & 0.036 & 17.65 & 18.80 & bal. & 3.00 & 5.00 & 1.05 & 1.22 & 0.0037 & trace & 1.20 & 1.53 & 6.80 \\
\hline
\end{tabular}

Age hardening study on Alloys 11,13 and 15 was conducted with $950^{\circ} \mathrm{C} / 1 \mathrm{~h} / \mathrm{WC}$ solution treatment and followed by aging at $710,730,760,780,800$ and $820^{\circ} \mathrm{C}$ for 1,3 , 8,12 and $20 \mathrm{hrs}$. For stability study the specimens after $950^{\circ} \mathrm{C} / 1 \mathrm{~h} / \mathrm{WC}+760^{\circ} \mathrm{C} / 8 \mathrm{~h} /$ WC were long time aged at $730^{\circ} \mathrm{C}$ for $200 \mathrm{hrs}$ again.

Creep tests on Group B Alloys were taken at $700^{\circ} \mathrm{C}$ and 500,550 and $600 \mathrm{Mpa}$. All the specimens were heat treated as follows:

$$
1000^{\circ} \mathrm{C} / \mathbf{1 h} / \mathbf{A C}+700^{\circ} \mathrm{C} / 8 \mathrm{~h} \rightarrow \mathbf{F} . \quad \text { C. } 50^{\circ} \mathrm{C} / \mathbf{h}+600^{\circ} \mathrm{C} / 8 \mathrm{~h} / \mathbf{A C} \text {. }
$$

Alloy 975 and 976 powder products were HIPed at $1150^{\circ} \mathrm{C}, 1000$ bar for 4 hrs and followed by $1180^{\circ} \mathrm{C}$ homogenization treatment for $72 \mathrm{hrs}$. For fully solution of $\gamma^{\prime \prime}, \gamma^{\prime}$ and $\delta$ phases the solid solution treatment temperature was chosen as $1025^{\circ} \mathrm{C}$. Multi-step aging was designed for special reason, Ist step $T^{\circ} \mathrm{C} / \mathrm{h}$ for precipitation $\sim 200 \AA$ average size of $\gamma^{\prime}$ and followed with certain cooling rate to promote $\gamma^{\prime \prime}$ nucl eation directly at $\gamma^{\prime}$ phase; last step was chosen as $650^{\circ} \mathrm{C} / 16 \mathrm{~h} / \mathrm{AC}$ for getting fully aged structure. Long time aging of Alloy 975, 976 and 976 with appropriate heat treatment (designated as $976 \mathrm{M}$ ) was conducted at 650,700 and $750^{\circ} \mathrm{C}$ for $5000 \mathrm{hrs}$. Hardness test was chosen as the simplest indication of strengthening effect. Microstructure and $\gamma^{\prime \prime}, \gamma^{\prime}$ morophology observation was mainly conducted on thin foil TEM with bright and dark field images. Typical compact morphology of $\gamma^{\prime \prime}$ and $\gamma^{\prime}$ was analysed by high resolution el ectron micr oscopy (HREM). 


\section{Results and Discussion}

Age hardening

Age hardening curves of Alloy 11,13 and 15 at $710,730,760,780,800$ and $820^{\circ} \mathrm{C}$ are shown in Fig. 1. All the alloys possess typical age hardening effects. However, all three Alloys do not reach peak hardness at $710-730^{\circ} \mathrm{C}$ aging for $20 \mathrm{hrs}$. All the Alloys reach the peak hardnesses at $760^{\circ} \mathrm{C}$ for $8 \mathrm{hrs}$. Age hardening effect is promoted by raising temperature. However, Alloys characterize serious softening when the aging temperature is beyond $800^{\circ} \mathrm{C}$. Age hardening effect is clearly dependent on $\mathrm{Nb}$ content. Age hardening curves are very close for Alloys 11 and 13, although 2 Alloys contain different levels of $\mathrm{Nb}$ (Alloy 11-5. 08\% $\mathrm{Nb}$, Alloy 13-4. 38\% $\mathrm{Nb}$ ). Age hardening effect is much lower in Alloy 15 than in Alloys 11 and 13 because of its very low content of $\mathrm{Nb}(3.44 \%)$, al though it contains very high Mo $(7 \%)$.
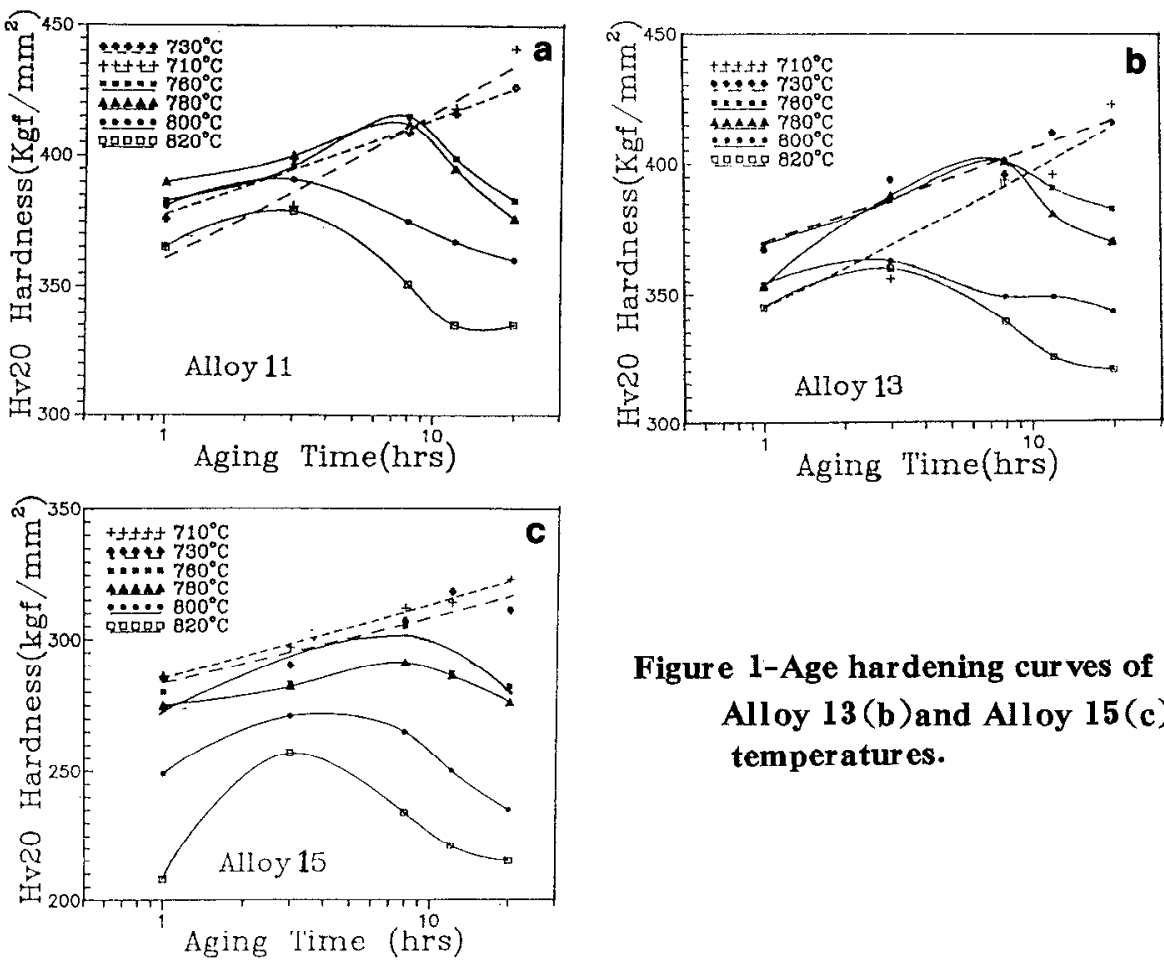

Figure 1-Age hardening curves of Alloy 11 (a), Alloy 13 (b) and Alloy 15 (c) at different temperatures.

Table II shows hardnesses of 3 Alloys for long time aging $\left(730^{\circ} \mathrm{C} / 100\right.$ and $\left.200 \mathrm{~h}\right)$ after reaching peak hardnesses at $760^{\circ} \mathrm{C} / 8 \mathrm{~h}$. For Alloys 11 and 13 after 100 and $200 \mathrm{~h}$ long time aging hardnesses keep same levels al most as the hardnesses of $760{ }^{\circ} \mathrm{C} / 8 \mathrm{~h}$ aging. However, the hardnesses of Alloy 15 are increasing continiously from $\mathrm{Hv} 311$ till 375 for $7300^{\circ} \mathrm{C} / 200 h$ aging.

Table II Hardnesses Hv $20\left(\mathrm{kgf} / \mathrm{mm}^{2}\right)$ of Alloys 11, 13, 15 after $730^{\circ} \mathrm{C}$ long time aging.

\begin{tabular}{|c|c|c|c|}
\hline Alloy & $760^{\circ} \mathrm{C} / 8 \mathrm{~h}$ & $700^{\circ} \mathrm{C} / 8 \mathrm{~h}+730^{\circ} \mathrm{C} / 100 \mathrm{~h}$ & $760 \mathrm{C} / 8 \mathrm{~h}+730 \mathrm{C} / 200 \mathrm{~h}$ \\
\hline 11 & 415 & 415 & 415 \\
\hline 13 & 401 & 404 & 404 \\
\hline 15 & 311 & 343 & 375 \\
\hline
\end{tabular}




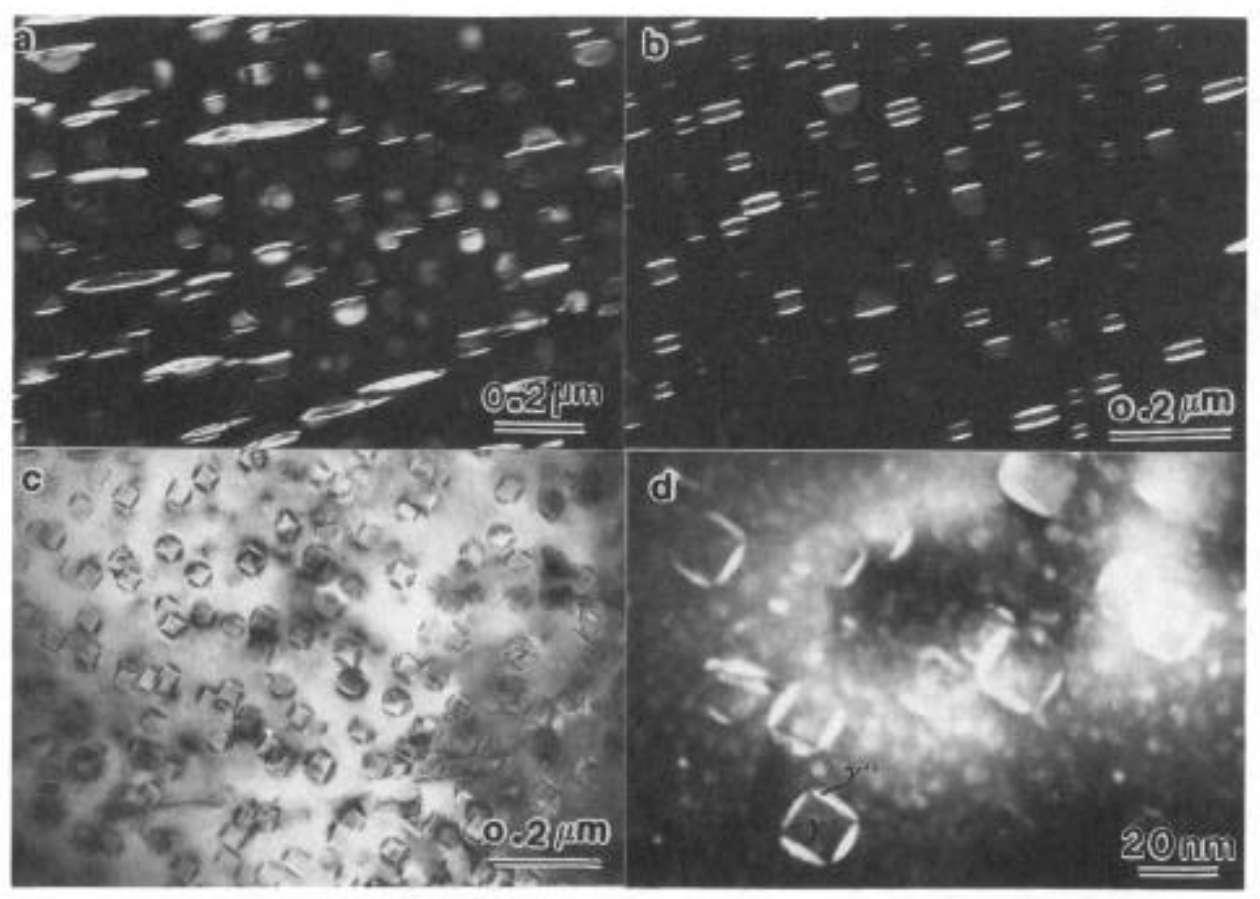

Figure 2-Associated precipitation and compact morphology of $\gamma^{\prime \prime}$ and $\gamma^{\prime}$ in Alloy 13 (adark field) and Alloy 15 (b,d-dark field, c-bright field) after long time aging at $730^{\circ} \mathrm{C}$ for $200 \mathrm{hrs}$.

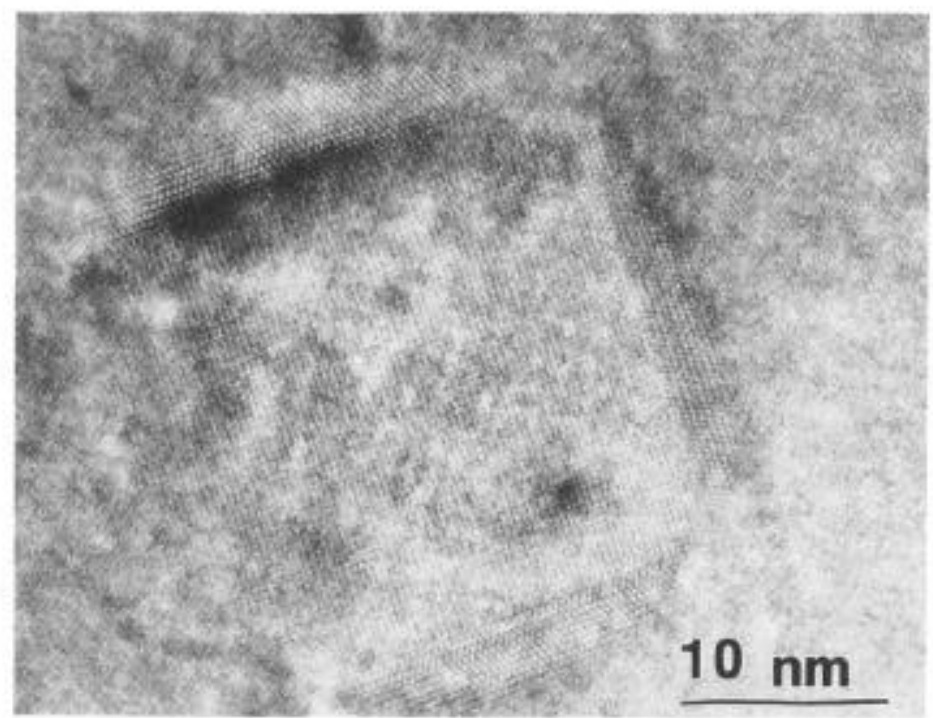

Figure 3-HREM image of compact morphology of $\gamma^{\prime \prime}$ and $\gamma^{\prime}$ in Alloy 15 after longtime aging at $730^{\circ} \mathrm{C}$ for $200 \mathrm{hrs}$. 
TEM and HREM observation

Chemical composition of Alloy 11 is close to INCONEL 718 but with a little high contents of $\mathrm{Al}$ and $\mathrm{Ti}$ and higher ratios of $\mathrm{Al}+\mathrm{Ti} / \mathrm{Nb}$ and $\mathrm{Al} / \mathrm{Ti}$. Most of $\gamma^{\prime \prime}$ and $\gamma^{\prime}$ are precipitated separately from $\gamma$-matrix during the aging and intensively grow especially for main strengthening phase $\gamma^{\prime \prime}$. Two types of combined precipitation of $\gamma^{\prime \prime}$ and $\gamma^{\prime}$ are found in modified 718 Alloys 13 and 15 , especially.

(A) Associated precipitation of $\gamma^{\prime \prime}$ and $\gamma^{\prime} \cdot \gamma^{\prime \prime}$ can be bound up with almost hemispherical $\gamma^{\prime}$ or can be alternatively precipitated as a "sandwich" morphology as shown in Fig. 2 (a) and (b).

(B) Compact morphology of $\gamma^{\prime \prime}$ and $\gamma^{\prime} \cdot \gamma^{\prime \prime}$ can directly precipitate at cuboidshaped $\gamma^{\prime}$ particles coated with its shell as shown in Fig. 2 (c) and (d).

These two types combined precipitation of $\gamma^{\prime \prime}$ with $\gamma^{\prime}$ are different to separate precipitation of $\gamma^{\prime \prime}$ and $\gamma^{\prime}$ as the mixture of disk-shaped $\gamma^{\prime \prime}$ and round $\gamma^{\prime}$ particles in conventional INCONEL 718.

$\gamma^{\prime \prime}$ is the most inportant strengthening phase in Alloy 718 . However, separately precipitated disk-shaped $\gamma^{\prime \prime}$ grows rapidly in conventional INCONEL 718 beyond $650^{\circ} \mathrm{C}$. Same tendency occurs in modified 718 Alloys, that separately precipitated $\gamma^{\prime \prime}$ grows rapidly and the average length of $\gamma^{\prime \prime}$ disks can be increased from $\sim 200 \AA \quad\left(760^{\circ} \mathrm{C} / 8 \mathrm{~h}\right.$ aging) to almost $1700 \AA$ (after $730^{\circ} \mathrm{C} / 200 \mathrm{~h}$ long time aging) as shown in Fig. 2 (a) for Alloy 13. The $\gamma^{\prime \prime}$ coarsening rate is as high as $7 \AA / h$. However, the associated precipitated $\gamma^{\prime \prime}$ bound with hemispherical shaped $\gamma^{\prime}$ grows slowly as shown in the same picture (Fig. 2a, b) for good comparison. Especially the $\gamma^{\prime \prime}$ in compact morphology of $\gamma^{\prime \prime}+$ $\gamma^{\prime}$ grows more slowly as shown in Fig. 2 (d). The $\gamma^{\prime \prime}$ coarsening rate is much lower $(\sim 3 \AA / h)$ for Alloy 15 in comparison with Alloy 11 and 13. These results clearly show higher thermal stability of main strengthenign phase of $\gamma^{\prime \prime}$ in modified 718 Alloys with associated precipitation or compact morphology of $\gamma^{\prime \prime}$ and $\gamma^{\prime}$.

Compact morphology of $\gamma^{\prime \prime}$ and $\gamma^{\prime}$ is shown in detail on Fig. 3 by high resolution electron microscopy image. The interfaces of $\gamma^{\prime} / \gamma^{\prime \prime}$ and $\gamma^{\prime \prime} / \gamma$ will be studied further.

Associated precipitation and compact morphology of $\gamma^{\prime \prime}$ and $\gamma^{\prime}$ can be formed in modified 718 Alloys with higher contents of $\mathrm{Al}(\geqslant 1.0 \%)$ and $\mathrm{Ti}(\geqslant 1.0 \%)$ and higher ratios of $\mathrm{Al}+\mathrm{Ti} / \mathrm{Nb}$ and $\mathrm{Al} / \mathrm{Ti}$ at different levels of $\mathrm{Nb}(\sim 5.5 \% \mathrm{Nb}$ for $\mathrm{Alloy} 1,2$; $\sim$ $5.1 \% \mathrm{Nb}$ for Alloy 4, 6 and $\sim 4.75 \% \mathrm{Nb}$ for Alloy 7, 9, see Fig 4a, b, c). However, $\gamma^{\prime \prime}$ and $\gamma^{\prime}$ separately precipitate from $\gamma$-matrix in conventional Alloy 718 with lower contents of $\mathrm{Al}(\sim 0.5 \%)$ and $\mathrm{Ti}(\sim 1.0 \%)$ and lower ratios of $\mathrm{Al}+\mathrm{Ti} / \mathrm{Nb}=0.70$ and Al $/ \mathrm{Ti}=0.79$ (see Fig 4d). 


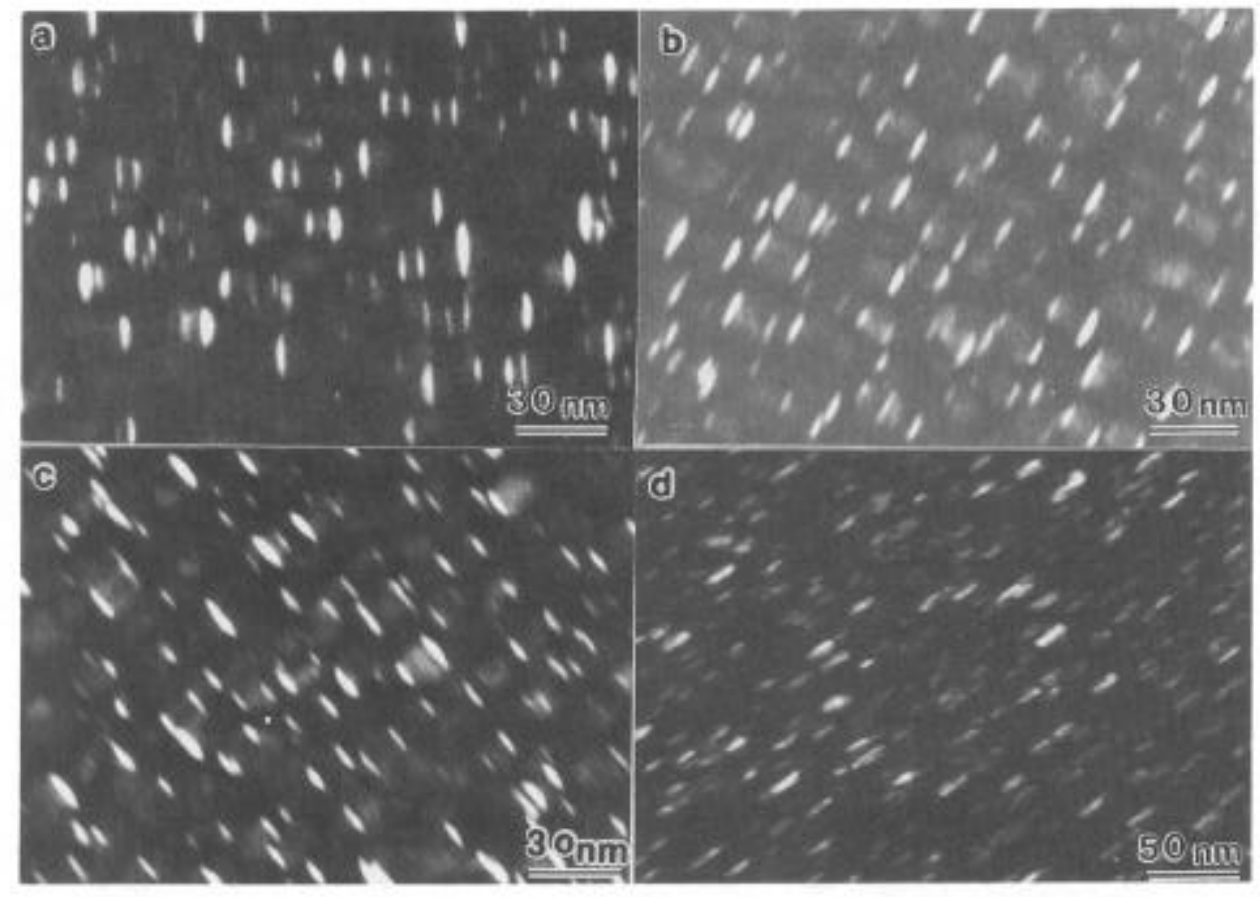

Figure 4-Associated precipitation and compact morphology of $\gamma^{\prime \prime}$ and $\gamma^{\prime}$ in modified 718 Alloy 1 (a), Alloy 6 (b), Alloy 9 (c) and separate precipitation of $\gamma^{\prime \prime}$ and $\gamma^{\prime}$ in conventional INCONEL 718 (Alloy 10-d).

Creep tests.

Creep fracture lives (tr) at $700 \mathrm{C}$ and different stresses (500-600MPa) increase with the atomic sum of $\mathrm{Al}, \mathrm{Ti}$, and $\mathrm{Nb}$ and reach the peaks at $\mathrm{Al}+\mathrm{Ti}+\mathrm{Nb}=7$, then mildly decrease again when $\mathrm{Al}+\mathrm{Ti}+\mathrm{Nb}$ increases furthur. (see Fig $5 \mathrm{a}$ ). In consideration of the complex effect of $\mathrm{Al}, \mathrm{Ti}$, and $\mathrm{Nb}$ a coefficient of $\mathrm{K}=\sqrt{(\mathbf{A l}+\mathbf{T i} / \mathrm{Nb})^{2}+(\mathbf{A l} / \mathbf{T i})^{2}}$ - $\mathrm{Nb}$ is suggested for creep lives eval uation. Creep rupture lives are almost proportional to the coeffieient $K$ at the stress levels of 500,550 and $600 \mathrm{MPa}$ for $700^{\circ} \mathrm{C}$ (see Fig. $5 \mathrm{~b})$. Creep rupture lives of almost all modified 718 Alloys in Group B are longer than conventional Alloy 718 (Alloy 10 in Fig $5 \mathrm{a}$ and b). It indicates that associated precipitation and compact morphology of $\gamma^{\prime \prime}$ and $\gamma^{\prime}$ in modified Alloy 718 with higher $\mathbf{A l}+\mathbf{T i}$ $+\mathrm{Nb}$ and higher ratios of $\mathrm{Al}+\mathrm{Ti} / \mathrm{Nb}$ and $\mathrm{Al} / \mathrm{Ti}$ possess with not only higher thermal stabil ity but also longer creep rupture life.
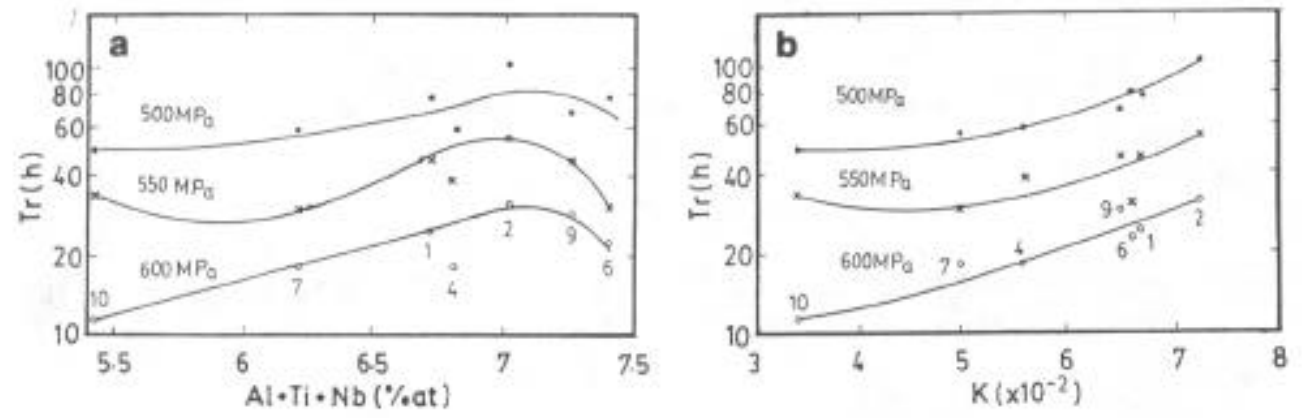

Figure 5-The dependence of $700^{\circ} \mathrm{C}$ creep fracture time (tr) on atomic sum of $\mathrm{Al}+\mathrm{Ti}+$ $\mathrm{Nb}-$ (a) and on coefficient $\mathrm{K}$ at 500, 550,600MPa- (b). 


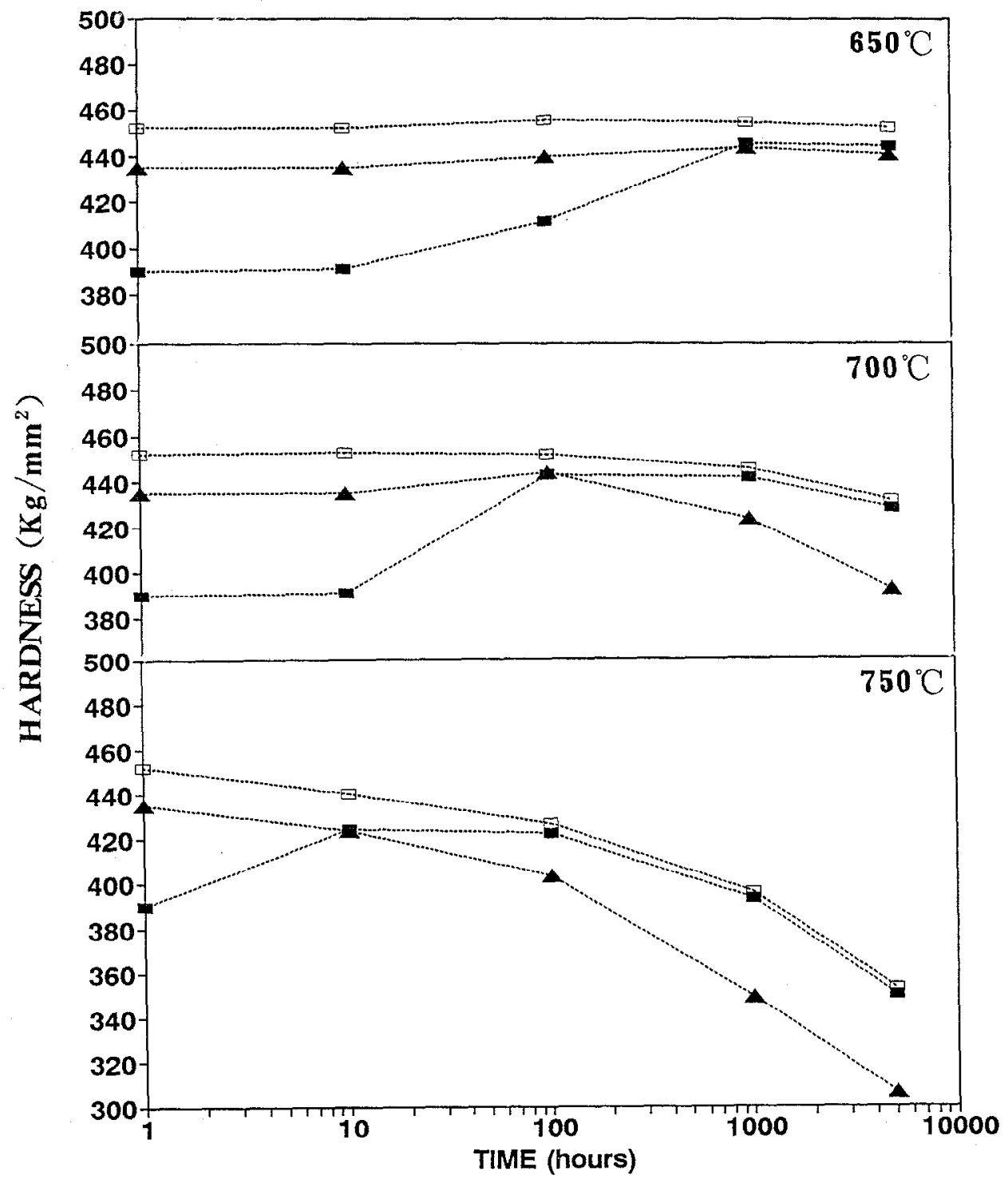

Figure 6-The dependence of hardness (Hv20) on long time aging (5000hrs) at 650, 700 and $750^{\circ} \mathrm{C}$ for alloy specimens 975,976 and $976 \mathrm{M}$. 

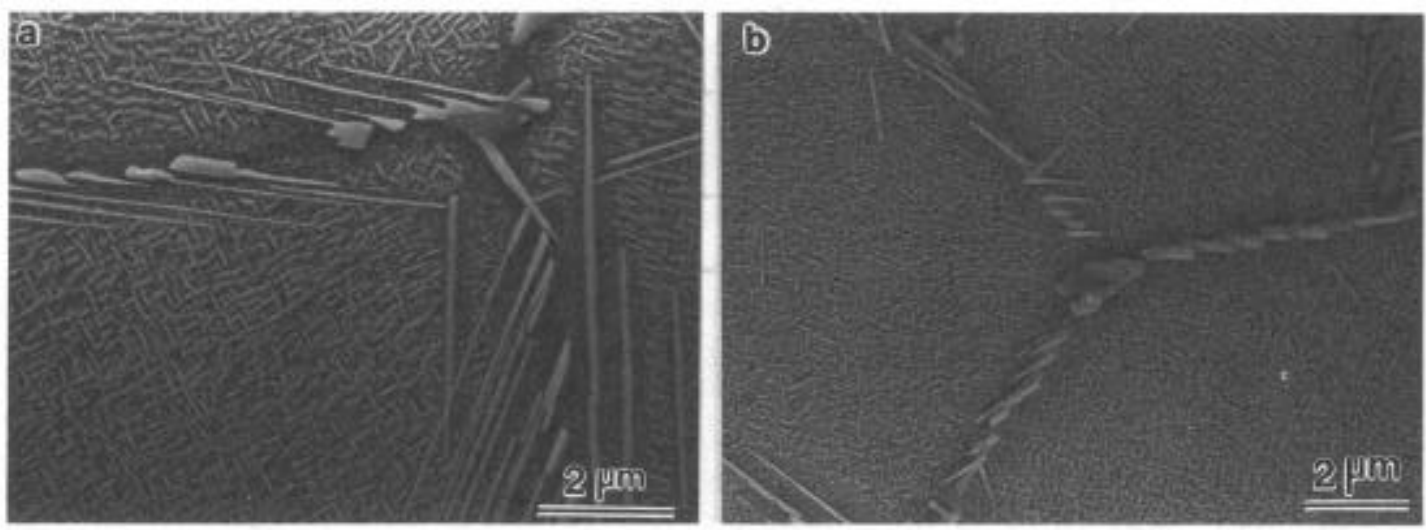

Figure 7-SEM structure comparison of 975 (a) 976 (b) after long time exposure at $750^{\circ} \mathrm{C}$ for $1000 \mathrm{hrs}$.

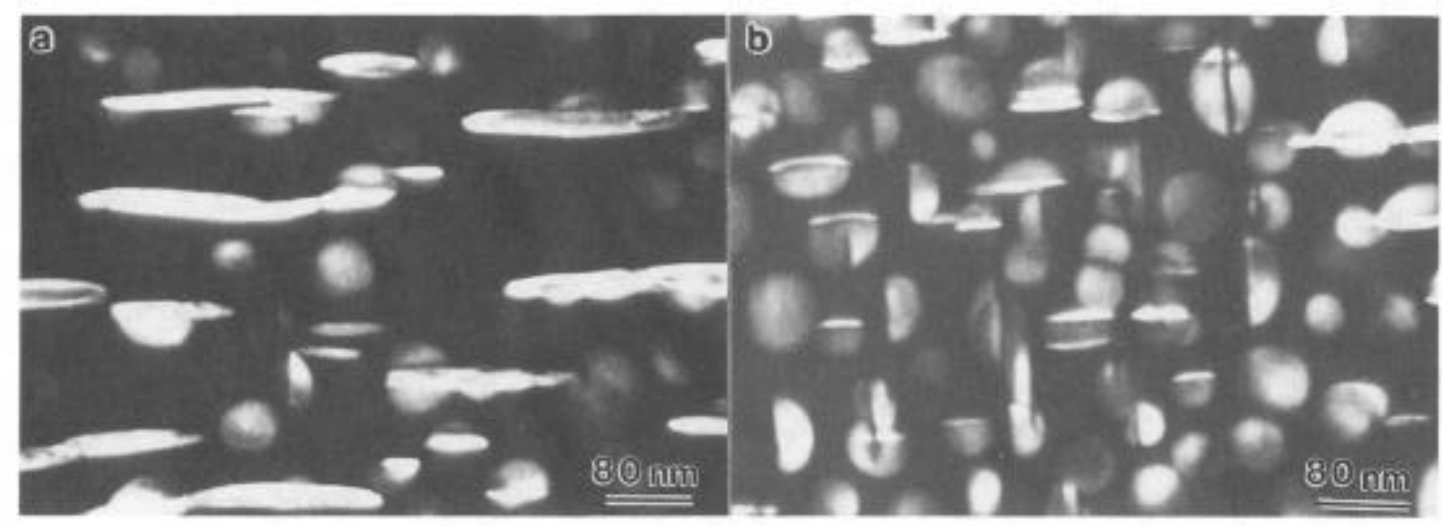

Figure 8-TEM dark field images of $\gamma^{\prime \prime}$ and $\gamma^{\prime}$ precipitates after long time exposure at $750 \mathrm{C}$ for $1000 \mathrm{hrs}$ in alloy specimens of 975 (a) and $976 \mathrm{M}$ (b). 
Long time structure stability.

A modified 718 (Alloy 976) was specially designed for long time structure stability study in comparison with Super 718 Alloy (Alloy 975). Both alloys were heat treated as $1025{ }^{\circ} \mathrm{C} / 30 \mathrm{~min} / \mathrm{AC} .+720^{\circ} \mathrm{C} / 8 \mathrm{~h} \rightarrow \mathrm{FC} .50^{\circ} \mathrm{C} / \mathrm{h}+620^{\circ} \mathrm{C} / 8 \mathrm{~h} / \mathrm{AC}$. For obtaining compact morphol ogy of $\gamma^{\prime \prime}$ and $\gamma^{\prime}$ a special heat treatment $1025^{\circ} \mathrm{C} / 30 \mathrm{~min} / \mathrm{AC}+850^{\circ} \mathrm{C} / 30$ min $\rightarrow 300{ }^{\circ} \mathrm{C} / \mathrm{h} \rightarrow 750^{\circ} \mathrm{C} \rightarrow 50^{\circ} \mathrm{C} / \mathrm{h}+650^{\circ} \mathrm{C} / 16 \mathrm{~h} / \mathrm{AC}$ was conducted for Alloy 976 (designated as $976 \mathrm{M}$ ). Fig. 6 shows the dependence of hardness on long time aging (till $5000 \mathrm{hrs}$ ) at 650,700 and $750^{\circ} \mathrm{C}$ for alloy specimens 975,976 and $976 \mathrm{M}$. It clearly shows that $976 \mathrm{M}$ possesses with the highest hardness level at all aging temperatures. SEM observation gives a clear comparison that microstructure of $976 \mathrm{M}$ is more stable than 975 after $750^{\circ} \mathrm{C}$ aging for $100 \mathrm{hhrs}$ (see Fig. 7). TEM observation shows the rapid growth of disk-shaped $\gamma^{\prime \prime}$ in Alloy 975 (see Fig. 8a). However, $\gamma^{\prime \prime}$ bound with $\gamma^{\prime}$ as associated precipitation and compact morphology in Alloy 976M possesses with excellent ther mal stabil ity even at $750^{\circ} \mathrm{C}$ for $1000 \mathrm{hrs}$ (see Fig $8 \mathrm{~b}$ ).

\section{Concl usions}

1. Thermal stability and creep resistance can be improved in modified 718 Alloys by increasing the ratios of $\mathrm{Al}+\mathrm{Ti} / \mathrm{Nb}$ and $\mathrm{Al} / \mathrm{Ti}$ and the $\mathrm{Al}+\mathrm{Ti}+\mathrm{Nb}$ content above that of the conventional INCONEL 718.

2. The main structural factors for thermal stability improvement above $650^{\circ} \mathrm{C}$ are contributed by associated precipitation and compact morphology of $\gamma^{\prime \prime}$ and $\gamma^{\prime}$ because of the slow growth rate of $\gamma^{\prime \prime}$ bound with $\gamma^{\prime}$ in modified 718 Alloys at high temperature.

3. A modified 718 Alloy with appropriate heat treatment (976M) possesses with excellent thermal stability and strengthening effect even at $750^{\circ} \mathrm{C}$ long time aging for 5000hrs.

\section{References}

1. R. Cozar and A. Pineau, Metall. Trans, 4(1973), PP.47-59.

2. J. P. Collier, S. H. Wong, J. C. Phillips and J. K. Tien, Metall. Trans., 10A(1988), pp.1657-1666.

3. J.P Collier, A. O. Selius and J. K. Tien, Superalloys 1988, TMS(1988), pp. 43-52.

4. E. Andricu, R. Cozar and A. Pineau, Superalloy 718: Metallurgy and Applications, TMS(1989), pp.241-256.

5. E. Gou, F. Xu and E. A. Loria, Superalloy 718: Metallurgy and Applications, TMS (1989), pp.567-576.

6. M. Wang, Master Degree Thesis, Univ, of Sci. and Tech. Beijing (1989).

7. Q. Liang, Master Degree Thesis, Univ of Sci. and Tech. Beijing (1990).

8. E. Gou, F. Xu and E. A. Loria, Superalloy 718, 625 and Various Derivatives, TMS (1991), pp.389-396.

9. E. Gou, F. Xu and E. A. Loria, Superalloy 718, 625 and Various Derivatives, TMS (1991), pp. 397-408. 